\title{
The Nature of the Firm and Peculiarities of the Corporation.
}

\author{
Tony Lawson ${ }^{1}$ \\ Faculty of Economics, Sidgwick Avenue, Cambridge, CB3 9DD \\ Tony.Lawson@econ,cam.ac.uk \\ Aug 272014
}

\begin{abstract}
Insights from social ontology are utilised to provide a novel, or at least clarified, conception of the firm. The latter is shown to be a particular form of social entity that is both of an economic and legal nature. The limited company or 'corporation' is shown to be a specific form of firm. A central distinguishing feature of the argument is that positioning matters in social identity constitution and different sorts of phenomena are positioned in different ways. The company/corporation is constituted in a manner that is a hybrid of other forms of positioning. Notions like legal fiction and legal personality that abound in the related literature, often in confused ways, are also clarified. Various consequences are drawn for further analyses at the levels of method, theory and policy.
\end{abstract}

Keywords: Firm, corporation, ontology, social positioning, community, artefact, legal fiction, juridical person, rights, obligations, function.

JEL Codes: A1, B4, D2, D7, K00, L1, L2, L3, M1, M2, N10, P12, P16, P48

\section{Introduction}

More than three quarters of a century after Ronald Coase (1937) first advanced his theory of the firm, economists, legal theorists and others still debate the firm's nature. Various issues bearing on this persist in being unresolved matters of contention and confusion.

Prominent amongst the latter is the matter of whether or not the firm is a real entity, a collection of phenomena of some sort, a structure of relations, or something else. A second issue is the manner, if any, in which the firm can legitimately be characterised as legal in nature. Although many observers accept that the firm does have a legal as well as an economic aspect to its constitution, there remains significant confusion over where processes of economic and of legal determination begin and end. A third issue of contention and confusion is the nature of the firm qua a limited company or corporation, and the meaning of the associated process of incorporation. Is the corporation a mere mental construct, a legal device of some sort, or something else? A fourth, albeit related, issue is the meaning of the claim, widely in evidence, that the firm qua corporation is a legal fiction. What precisely does the latter term mean, how does it relate to the notion of an ontological fiction, and what does its use, if legitimate, imply for the constitution of the corporation? Is it in fact the case, as some suggest, that a proper use of the category legal fiction in the relevant context amounts to the claim that the corporation does not exist at all, at least not as a kind of social entity? A fifth, and also related if seemingly distinct, issue is the meaning of the widely observed assertion that the firm qua limited company or corporation is a legal person. Does this entail in particular that such a firm can be conceptualised as an individual with motivations of its own? And so on.

${ }^{1}$ I must thank the Independent Social Research Foundation for generous funding of the research on which this paper draws. For helpful comments on an earlier draft I am additionally grateful both to three referees of the Cambridge Journal of Economics, and also, and especially, to Simon Deakin. 
These matters, all addressed below, are issues in social ontology of course. Yet somewhat surprisingly, perhaps, a questioning of the nature of the firm, and any addressing of the sorts of issues noted, seems mostly to be attended to, albeit usually all too briefly and mostly indirectly ${ }^{2}$, by contributors primarily motivated by substantive matters and issues of social policy; the topic appears rarely to be addressed by those working systematically on social ontology. As a result, any wider results of ontological theorising that bear relevance to the issues before us tend to be neglected. Whatever the reason for this ${ }^{3}$, here I do approach the topic from the point of view of explicit ontological elaboration, making explicit use of results defended elsewhere (Lawson 2012, 2013a, 2013b).

My central thesis, developed in due course, is that all of social phenomena that we identify are constituted through processes of social positioning (a feature that goes unnoticed in most social theorising). The firm I will argue is no exception, albeit an interesting example.

I start by briefly outlining aspects of the conception of social ontology defended elsewhere, focusing in the main on features of it that I take to be especially relevant to the task before me, namely that of elaborating the nature of the firm in general and the corporation in particular.

\section{The social domain}

By the social domain (or social reality) I understand the set of all phenomena whose existence depends necessarily on human interaction.

\footnotetext{
${ }^{2}$ Indeed, and following Coase's lead, most contributors, even when presenting themselves as addressing the nature of the firm, have actually addressed mostly different questions. For example, Coase's starting points are the assessment that according to 'economic theory' resource allocation is best achieved via the price mechanism, and the observation that this does not happen inside the firm. Thereupon Coase sets about questioning not the nature of the firm but why firms (interpreted in passing as forms of organisation) exist at all. Thus Coase writes: "But in view of the fact that it is usually argued that co-ordination will be done by the price mechanism, why is such organisation necessary? [....] Yet, having regard to the fact that if production is regulated by price movements, production could be carried on without any organisation at all, well might we ask, why is there any organisation" (Coase, 1937, p. 388). He later adds: "Our task is to attempt to discover why a firm emerges at all in a specialised exchange economy" (Coase, 1937, p. 389). (Coase's answer as to the reason a firm can exist, of course, runs in terms of there being transactions costs involved in purchasing everything on the open market, some of which a firm can often minimise or avoid altogether). If Coase, then, pursues a different question to that expressed in the title of his paper, others have followed suit and, often under the same head, also addressed instead (not the firm's nature but) why the firm might exist. In this, some have sought to develop Coase's theory (e.g., Williamsom, 1975, 1987), whilst most have suggested alternatives (for a varied selection of alternative explanations see for example Milgrom and Roberts, 1992; Fransman, 1994; Jensen and Meckling, 1976; March and Simon, 1958; Nelson and Winter, 1982; Rajan and Zingales, 1998; Blair, 2004; and so on). Although many such contributions are presented (or interpreted) as advances on the arguments of Coase, few of the noted theoretical developments actually contradict Coase's minimalist if mostly implicit conception of the nature of the firm in terms of the organised coordination of allocation and production via direction. Rather, like Coase's contribution, they concentrate instead on seeking an explanation of the firm's existence mostly on the presumption that standard economic theory claims that markets themselves could and ought to do everything. Any conception of the nature of the firm is mostly left implicit and certainly unelaborated. It is seemingly for this reason that the sorts of issues noted at the outset tend to be left unresolved rather than systematically addressed.

${ }^{3}$ One likely explanation of any such neglect by social ontologists turns on the fact that although broad philosophical conceptions are intended to cover the whole of social reality, they can be brought to bear on specific social phenomena only through their being supplemented with additional empirical claims and assessments. Where this is carried through, the danger, often realised, is that critical observers/commentators take themselves to undermine the ontological conception as a whole by casting doubt on particular empirical extras (see Fullbrook, 2009, chapter 4).

The alternative danger, however, arising where ontologists avoid engaging at a more empirical level, is that a perception is thereby encouraged that general or philosophical social ontology has little to contribute at the more substantive level, even at that of scientific ontology (that is, at the level of understanding the natures of specific social phenomena such as money, technology, the firm, etc.). For this reason, various relatively sympathetic commentators have indeed raised this worry in criticising my own apparent reluctance to embark more frequently on this route (again see Fullbrook, 2009, Chapter 4).
} 
A key category for the argument that follows is that of emergence, and in particular the emergence of social totalities. The term emergence just means the appearance of novelty or something previously absent or unprecedented. A totality is a system of organised, usually more basic and pre-existing, elements that reveals a coherence or integrity at the system level. Totalities emerge through the relational organisation (perhaps with some modification) of these pre-existing elements, the latter thereby being harnessed and organised as components (some of which will be organised so that they are tied to an environment in some way; emergence always occurs in a context). Clearly because the relational organisation appears along with any totality it too is an emergent. In the case of social totalities the elements so organised either may or may not themselves be socially constituted.

Any system or totality that so emerges is, qua an organised system, irreducible to the sum total of its components alone just because it is constituted in part by the manner in which the components are arranged or relationally organised. So, ontological reduction of a disaggregative sort is proscribed. Similarly any emergent powers of efficient causation of an emergent totality are causally irreducible in the sense of being predictable from the causal powers of these elements when considered apart from the manner of their eventual organisation of components of the totality. So, causal reduction of a simple sort is also proscribed $^{4}$ (see Lawson, 2013b).

Imagine the bricks, mortar, wood, panes of glass, cement, etc. that make up a house or church or dance hall, etc. are rearranged in a blind or random fashion. It is unlikely that the outcome would have either the form or the causal properties of the original building. The arrangement of the parts makes the latter feasible. This arrangement/organisation is a form of formal causation.

A house or church, etc., is, of course, but an artefact, and most, or anyway many fundamental social phenomena are not of this sort. In fact, as I have elsewhere argued at length, a very general and basic form of social entity or system is the community, with components comprising people and artefacts, and its organising relational structure consisting most especially of social positions and associate collective practices involving rights and obligations $^{5}$. Let me briefly elaborate.

\section{Social positions rights and obligations}

By a social position I mean something like University Lecturer, Bishop, Bus Driver, Employer and Employee, etc. (here I adopt the convention of capitalising the position but not the occupant). These are positions that individuals enter (or statuses they acquire), and through the occupancy of which they acquire the social (or better positional) identities associated with the positions. These are initial examples of social positioning, a notion that, as noted, will be central to all that follows (For an elaboration see e.g. Lawson, 1994, 1997, 2003, 2012, 2013a). Through being so positioned, individuals gain not only positional identities, but also access to rights and obligations, and so collective practices, associated with any position so entered.

\footnotetext{
${ }^{4}$ There are more sophisticated forms of the thesis of casual reduction that hold that emergent causal powers are (if not straightforwardly reducible to, nevertheless) explicable solely in terms of the causal powers of the components. However, I show elsewhere that this is generally not the case, and seemingly not at all so with respect to social causation (see Lawson, 2013b).

${ }^{5}$ An additional form of emergent social system is language.
} 
Thus an individual appointed to the position University Lecturer within the UK community acquires the identity of university lecturer and is allowed to follow various practices that are rights of being so positioned. These may include rights of use of university libraries and other research resources, of being paid by the state, etc. The individual is also not only allowed, but also expected, to follow various practices; these are the obligations of being so positioned, and may include giving lectures, and setting and marking exams, etc.

Where certain positioned individuals have access to a set of rights (and obligations), the latter are matched by the obligations (and rights) of others positioned differently. The right of a lecturer to use various university facilities is matched by the obligations of others differently positioned to fund, maintain and run those facilities, etc. Similarly the obligation of a lecturer to give lectures, say, are matched by the rights of students to attend/receive lectures.

It is the matching of specific rights of some to the obligations of others that constitute social relations. And it is the sets of positions, and associated positional social relations and collective practices that form the structure of human groups, systems or communities. The cement of such groupings consists especially in the human capacities for trusting and being trustworthy. If, typically, individuals either could not be, or were never, trusted to fulfil their positional obligations, society as we know it would fall apart (see Lawson 2012).

Here my focus is the community in particular. These, to repeat, are structured social entities that emerge from human interaction, and include human individuals amongst their components. Rarely, if ever, is a community self-standing anymore. Typically it is contained or nested within others (like a village [community] within a nation [community]). The defining feature of a community is a position that all its members occupy, so that the broadest or most abstract set of rights and obligations are held in common. Almost always there will be differentiations too, but these will be properties of, and sanctioned either within, or at the level of, a nesting (rather than a nested) community.

Consider a typical academic conference or workshop, as an example. At the most abstract level all participants have the right to attend each (or at least a subset of) session(s), seek to ask questions, and to participate generally, etc. Of course, in advance the organisers may (or may not) decide the list of speakers, chair-people and so on: there will likely be sub-groups with specific rights (and obligations) which all attendees are obliged to recognise. This subgroup may well indeed constitute a sub-community within a community. Who is allowed to join a specific sub-group or committee will depend on the decisions of those whose positions afford them the right to decide. This will vary from context to context. A large association may decide who joins a particular sub-group by way of the total membership voting on it. Or a small group of people with access to necessary funding may just decide to organise a conference, appropriating for themselves (as the organisers) whatever rights or privileges they desire. Potential attendees may decide whether or not to sign up to the conference according to perceptions of the openness (or cliquey-ness) of the organisers, amongst much else. So the community, the phenomenon that constitutes the basis of the more interesting social emergent, is highly context dependent in its form and structure and can be very fluid.

\section{Moving towards a conception of a firm: some preliminary issues}

I am suggesting, then, that social emergence involves the coming into being of novel totalities along with their structures, where the most general or common form of non-artefactual systems or totalities are communities. Processes whereby this emergence occurs are matters 
that I have discussed at length (under the head of morphogenesis) elsewhere, in relation to both the social and non-social realms (see especially, Lawson, 2013b). My specific contention here is that the firm is itself fundamentally a community of some kind, with an equally emergent organising structure amongst its properties.

In moving towards defending this assessment let me first observe that the term 'firm' is widely used as a generic form that covers various apparent subtypes. However, if there is contention and looseness over interpretations of the nature of the firm (the latter does not for example have a legal definition), there appears to be less debate over at least some of the subtypes that constitute examples. My starting point then will be, as it is in most processes of classification, to examine various (types of) phenomena that most observers appear to accept as non-contested, more or less quintessential, examples of the kind, nominally understood.

Clearly, though, as all social phenomena are properties of a specific wider-community, I must, at least at the outset, focus on examples of such phenomena within a definite widercommunity, and here I focus on the UK. As it happens most of the features I discuss have counterparts and parallels in most modern capitalist countries; so the UK case can be considered illustrative of a wider picture at least in broad outline.

In the UK, the phenomena that seem most regularly and frequently and without question to answer to the name firm are, or include, those more formally known as sole trader, business partnership and limited company. These then are my starting examples. And it is immediately clear that each of these is indeed a form of community. That is, each of these is a coherent totality of sorts, with members, even if these occasionally consist only in directors or company secretaries, organised via positions and associated rights and obligations (that I shall consider in a bit of detail eventually below). Notice incidentally that the term sole trader does not mean an individual working alone, but rather a configuration in which a single individual assumes responsibility for the business. Often there are numerous employees or 'staff', but unlike in other business communities a single individual can appropriate all aftertax business' profits (as I say more details are given below).

Clearly, many accounts of the firm are not fundamentally at odds with the assessment I am maintaining; they merely do not spell out (or explicitly recognise) that it is indeed a community that is presupposed as the basic unit in their analyses. Rather, from

Coase onwards, most contributors on the topic have tended to write in terms of the firm as an organisation, with the organisation often clearly presumed to involve human beings in particular relations. Rarely though have contributors explored the nature of their subject at this level.

In fact the reference to the firm as an organisation itself encourages problems, just because the term organisation, when so used, denotes, for the contributions in questions, both the totality itself as well as its relational (organising) structure. As we have seen the two, the totality and its organising structure, emerge simultaneously but are not identical. In social theory more widely the use of the term organisation in this dual manner leads often to the two features (the totality and its relational structure) being conflated, usually with one or the other feature consequently being neglected (see Lawson 2013).

It seems likely that this has occurred specifically in theorising the firm. Thus, in the case where the result is a relative neglect of organising structure, conceptions prevail of the firm $q u a$ a totality as (i) analogous to its components (for example the firm interpreted as 
analogous to a human individual ${ }^{6}$ ); as (ii) a (mere) collection of its components (for example, by treating the firm as a collection of individuals, or of assets ${ }^{7}$ ); or as (iii) in causal interaction with its components (often described as the process of 'reconstitutive downward causation' or simply as 'downward causation', as if a totality can somehow act 'down' on its own parts as opposed to through them $^{8}$ ).

\section{Where the conflation (resulting from slippage in use of the term organisation) has resulted} instead in a neglect of the totality at the expense of structure, a view encouraged is that (an organising) structure can somehow exist without anything being organised (for example that the firm is somehow a mere nexus of some sort); so that any reference to anything more than structure must be talk of a fiction or some $\operatorname{such}^{9}$.

Either sort of conflation is likely encouraged by the limitations of the other, of course. In particular, any conception of a firm as mere organising structure may be a response to the idea that the only entity conception on offer in earlier texts has it that the firm is analogous to a human individual ${ }^{10}$. Though the latter conception is certainly problematic, conceptual

\footnotetext{
${ }^{6}$ This particular entity view is very often associated with Gierke's four-volume Das deutsche Genossenschaftsrecht, and in particular to Maitland's translation of parts of Gierke (1900) into English. In his translator's introduction, Maitland writes of the firm or corporation that it:

"is no fiction, no symbol [...] no collective name for individuals, but a living organism and a real person, with body and

members and a will of its own. Itself can will, itself can act [....]. It is not a fictitious person [...] It is a group-person, and its will is a group-will" (Maitland in Gierke, 1900, p. xxvi)

Although this formulation is not without insight it is easy to see why many might react against it, not least to the notion that it is a 'living organism' or a 'real person'. Talk of its possessing a 'body' and a 'will of its own' does encourage the treatment of the firm as somehow analogous to a human individual.

${ }^{7}$ Thus, for example, Grossman and Hart (1986: 693) "define the firm to consist of those assets that it owns or over which it has control"; and (Hart and Moore, 1990) "identify a firm with the assets it possesses" (p. 1120). The sorts of problems that arise here are manifest in the difficulties of presenting such a position. What specifically is the 'it' in these two sentences? Seemingly in each case the 'it' refers to the firm. But then the firm cannot be or consist in "those assets...", otherwise assets would own and control themselves. Even in these formulations something more is presupposed. Nor can we merely drop all references to terms like ownership and control, and state that the firm is merely a collection of assets, for then the question arises as to which of all the assets in the world to interpret as constituting any particular firm. Relations of some sort, and in particular those relating to the control (access to, use and disposal of) assets, are necessary to distinguish any given firm. But once these are acknowledged, then an organising structure is rendered explicit, and so any conception of the firm as an aggregate or mere collection (for example of assets) is seen to be untenable.

${ }^{8}$ Wholes act through their parts acting, and their parts are coordinated in their actions through the emergent irreducible relational structures that organise the lower level elements as (perhaps through modification) components of emergent wholes (see especially Lawson, 2013a, 2013b). Thus an army attacks through the actions of its soldiers (or guided weapons); a school educates through the interactions of its members; a football team scores through a player scoring. Parts of a whole, though, interact with, and relate directly to, not a whole but each other and the organising structure. An individual picks up a pen through the various interactions actions of the brain, nervous system, and muscles etc. (again see Lawson, 2013a, 2013b).

9 Thus focusing in particular on Limited Liability companies, and avoiding conceptions of emergent social totalities, John Searle writes "[...] Limited liability companies have no physical existence (that is why they are called 'fictitious persons')" (2010, p. 115). For a lengthy assessment and response, see Lawson 2014 b.

Whether they intend it or not this sort of conclusion is also at least encouraged by those who insist that the firm is best treated as merely a 'nexus of contracts' (see e.g., Jensen and Meckling, 1976; Armen Alchian, 1984; Alchian and Susan Woodward, 1988; Steven Cheung, 1983). Thus Jensen and Meckling (1976), who brought to prominence the idea that the firm is but a 'nexus of contracts', write:

"It is important to recognize that most organizations are simply legal fictions which serve as a nexus for a set of contracting relationships among individuals [....]" (Jensen and Meckling, 1976, p. 310).

This sort of formulation easily underscores the idea that that any notion of the firm (or 'organisation') as a totality, as an entity that is more than the contracting relations, is fictitious in an ontological sense, that any idea of the firm as organisation is a mere artificial construction lacking a referent. I will explore below what a legal fiction actually is.

${ }^{10} \mathrm{In}$ advancing their idea of a firm as a nexus of contracts Jensen and Meckling are clearly seeking to distance themselves from the idea that the firm is an individual. This they clearly suppose is the dominant entity view of the firm and it is a conception these authors seek to avoid in proposing that the firm be treated as a nexus of contracting relationships:

"Viewing the firm as the nexus of a set of contracting relationships among individuals [...] serves to make it clear that the personalization of the firm implied by asking questions such as "what should be the objective function of the firm?" or
} 
difficulties disappear once we recognise the alternative entity notion, namely that the firm is a form of community.

Clearly all such formulations as those noted, and others like them, are easily identified as untenable once it is recognised that totalities: 1) are real; 2) possess equally real organising structures; 3 ) are formed out of elements that, through being relationally organised, come to form components; 4) are irreducible to these elements when the latter are unorganised; but 5) are able to act only though the actions of these elements when organised as components (see Lawson, 2012, 2013b).

Other contributions do avoid such conflations, though usually without giving much emphasis to these sorts of issues. At least some of these do explicitly interpret the firm as a community ${ }^{11}$. However, the contributions in question seem mostly to use the term community either without elaboration ${ }^{12}$, or else in effect interpret a community as a special type of social entity or grouping or 'organisational form', distinguished by a reliance upon either (various) conceptions of trust ${ }^{13}$ or some other entity-delimiting factor ${ }^{14}$.

I am arguing, in contrast, that all social 'organisational forms', indeed all social entities that include human beings as components, are forms/examples of communities, and indeed that all are organised through relations of rights and obligations which rest on the exercise of human capacities of trusting and being trustworthy, so that trust and trustworthiness are necessarily all pervasive and basic ${ }^{15}$. In short, if to repeat, I am using the term community generically as any relationally organised social emergent, or 'organisational form' that includes human beings amongst its components ${ }^{16}$.

With all this in mind, then, I turn to my primary questions and concerns. If the firm is a form of community, what precisely is the form or forms it takes? Moreover, what is the process whereby a community is constituted as a firm type? For example, can any community acquire the status of firm (or specifically that of sole trader, business partnership, or limited company) simply by its members declaring it to be a particular type of firm? Or is some more

\footnotetext{
"does the firm have a social responsibility?" is seriously misleading. The firm is not an individual" (ibid, p.311, emphasis in the original).

${ }^{11}$ See for example, Bruce Kogut and Udo Zander, 1993, 1995, 1996; Paul Adler, 2001; Heckscher and Adler, 2006; Siobhan O'Mahony and Karim Lakhani, 2011.

12 See e.g., Kogut and Zander, 1993, 1995, 1996. Thus Kogut and Zander argue that "Firms are social communities that specialise in the creation and transfer of knowledge" (1993, p. 365), but the term community (as in their Zander and Kugut, 1995) is not elaborated, and rarely actually used. Nor is it elaborated in Zander and Kugut, 1995) or even in Kugut and Zander, 1996, where these authors do observe that "Through membership in a social community called the firm, identity is developed that changes the character and quality of human discourse and behaviour", but thereupon they never mention the term again.

${ }^{13}$ For example see Paul Adler, (2001)

${ }^{14}$ Such factors, may for example be geographical, Christopher Marquis and Julie Battilana, 2009; knowledge sharing, Heckscher and Adler, 2006; Bechky 2003a, 2003b; cooperation on technology and innovation, Tushman and Rosenkopf, 1992; Aldrich and Ruef, 2006; and so on). For a recent comprehensive overview, that also adopts a delimited conception of community, see Siobhan O’Mahony and Karim Lakhani (2011).

${ }^{15}$ Moreover, my primary concern here is not, as it is with most existing contributions (e.g Adler 2001) with identifying an 'organisational form' that is either preferable or becoming dominant, but with systematising features that are common to them all. From the perspective advanced here specifically, any questioning of the preferred organisational form of a firm will necessarily be an assessment not of whether it is a community but more of the type of community it will be (on this see also George Lakoff, 1996).

${ }^{16}$ This means that in contrast to most other contributions, 'organisational forms' and 'coordination mechanisms' of price/market and hierarchy/authority are not contrasted with those of community/trust; rather the former two (if indeed themselves legitimately contrasted, see especially Schumpeter, 1976/1942) are both specific features of communities organised by sets of rights and obligations based on trust. Perhaps a better term for the focus of Adler and others would be reflexive collaboration. However that may be, with these distinctions hopefully clear I will return to the contributions that seemingly emphasise a narrower conception of community in due course.
} 
formal process typically involved?

I noted earlier that human individuals gain identities (for example as lecturers, employers, married partners, and presidents) by being appropriately positioned within a specific community. Of course the individuals so positioned will typically have capacities regarded as appropriate to the relevant positions. Though it is not impossible, it is unlikely that, say, a non-musician will be positioned as a member of an orchestra, etc. I now want to argue that similar considerations underpin processes whereby all social phenomena gain their identities including artefacts and even communities themselves. In particular, it is through being appropriately positioned that a community is constituted as a firm. Let me elaborate.

\section{The nature of social phenomena.}

In carving up the non-social realm, appropriately positioned human beings determine the basis of any particular kind. Of course, the goal typically is to 'carve nature at its joints'; but there is no unique way to do this. Once kinds or categories have been determined, thereafter it is nature, as it were, that decides which of the things or stuff around us qualify as tokens or 'members'. Thus if human beings decide that anything with chemical composition of $\mathrm{H}_{2} \mathrm{O}$ is a given kind called water, then whether or not various phenomena around constitute examples of water is not a matter that depends on deliberations or assessments; a liquid on my colleague's desk, say, is water (or not) independently of what I or others might speculate about its nature ${ }^{17}$.

In carving up the social realm things are different in that in very many cases at least (and specifically within appropriate given communities) human beings decide both the basis for distinguishing/constituting any kind or type and which phenomena or whatever are allowed to be members. Thus, a specific national community (typically through the actions of a subcommunity of representatives, and over time) may decide to accept the types or better positions of University Professor, Gynaecologist, Heart Surgeon, Taxi-Driver, Nurse and Prime Minister. But as we have already seen it is also the community (again typically through relevant sub-communities of representatives, and over time) that decide which of its members or participants are to be allocated to these positions.

The same is true, I now want to suggest, of the positioning/identification of artefacts and of communities. I focus on the former first.

The role of positioning in the acquisition/allocation of identities is easy to see with objects positioned as say paperweights (perhaps an attractively shaped sea pebble), or as passports

\footnotetext{
${ }^{17}$ It is important to recognise that this example of water, if familiar, is not representative of all practices of classification of non-social phenomena. It is typical in that the basis of the delineation is practical one. However, although we (especially through science) seek non-arbitrary delineations, the practical choice is not always in the end in terms of a substance possessing a unique and determinant chemical composition. In fact, in carving up the non-social realm classifications can and do emerge where, for example, 1) either/or conceptions make up a kind; or 2) two substances with identical chemical compositions are interpreted as members of different kinds. As an example of 1) the kind referred to as jade is made up of different substances each with their own chemical compositions (in fact, the substances that have been counted as jade have varied at different times and places in the course of human history). Currently the term jade is applied to two different rocks made up of different silicate minerals also known as nephrite and jadeitite. The former consists of the calcium- and magnesium-rich amphibole mineral actinolite, and has the chemical formula $\mathrm{Ca}_{2}(\mathrm{Mg}, \mathrm{Fe})_{5} \mathrm{Si}_{8} \mathrm{O}_{22}(\mathrm{OH})_{2}$; the rock called jadeitite is composed almost entirely of jadeite, a sodium- and aluminium-rich pyroxene mineral with composition $\mathrm{NaAlSi}_{2} \mathrm{O}_{6}$. As an example of 2), charcoal and diamonds are for practical reasons usually treated as different kinds, even though both are forms of carbon and so have an identical chemical composition. Even in the case of water, it might have turned out to be the case that in delineating it, those involved had lumped $\mathrm{H}_{2} \mathrm{O}$ together with the substance we call hard water that has a different chemical composition.
} 
and other devices for identifying human beings, or as accounting devices we call money, taking the form perhaps of notes and coins of certain compositions, and so on.

When, however, artefacts are particularly complicated and designed to perform a single complicated task, it may appear that they take on the relevant identities independently of being positioned in a human system/community. But ultimately this is not so. If, for example, an object manufactured to be positioned as a photocopier is washed up on an isolated island and some exotic tribe that inhabits the island (and which perhaps lacks a concept of electricity) positions the object in question as a table, then in this particular community a table is what it is. (Similarly a human individual may spend the entirety of her or his formative years training to be a professor, prime minister, opera singer, professional cricketer, Olympic skier, or whatever, but unless, or until, they are appropriately positioned they do not take on the status of a member of that position or kind).

I am going to argue that in a similar fashion a community takes on the identity of a firm by being appropriately positioned. However, there is an interesting complication, it will be seen, with the positioning of a community as a limited company or corporation.

Notice first that when an artefact is positioned as say a paperweight, a traffic beacon, a door or an identity card, certain of its causal capacities become interpreted as its (positional) functions. The latter are interpreted as functions within, and relative to, the system in which it is positioned. However, when a human individual is positioned as, say, a judge or prison officer, it is not the case that capacities possessed are interpreted as functions, but rather that the individual becomes the bearer or agent of novel positional powers, and specifically rights and obligations. Of course, positions and positional rights and obligations are typically in place in order that certain perceived needs of the system can be met by appropriately allocated occupants. So the positioning of human beings is typically also functional. But still in the case of the positioned human individual it is rights and obligations that are acquired.

The obvious question to raise of a community that becomes positioned as a firm, then, is whether a set of its causal capacities become interpreted as its functions (as a with a positioned artefact), or whether it acquires rights and obligations (like a positioned human being).

To give a brief overview of the position to be defended below, the answer to the question posed is that it can be, and typically is, the case both that causal capacities become interpreted as system functions and that rights and obligations are acquired. This is so just because a community, at least in the UK, and at the time I am writing, can be both positioned (or registered, in particular for tax purposes) as an 'ordinary' firm in the sense of a sole trader or a business partnership and, in principle, also further (or simultaneously) positioned (or incorporated) as a company (in the UK, or as corporation in the US). In the case where a community becomes positioned as an 'ordinary', i.e., as an unincorporated, firm a set of its capacities become interpreted as (or associated with) its (positional) functions. In the case where, or if, it becomes (further) positioned as a company, it acquires positional rights and obligations, just as a (positioned) human individual might. Indeed in being so positioned it is said to acquire the status of a legal person (a notion I elaborate upon below).

I believe this interpretation, which here I am merely summarising and foregrounding (involving a distinction between types of positioning and so between positional functions and positional powers), to be novel. I also suspect that it is a failure to distinguish the two 
separate forms of positioning and associated positional properties, that accounts for much of the confusion that continues to characterise the economic and legalistic discussion and debate over the nature of the firm.

Let me, then, elaborate and defend the assessment advanced in these last few paragraphs. I will first be advancing a formulation that I take to express a sustainable conception of the nature of the firm. Eventually I will focus on the specific nature of the limited company or 'corporation'.

\section{A conception of the firm}

As already noted, in the UK those entities that seem most regularly to answer to the name firm are, or include, communities more formally known as sole trader, business partnership and limited company. So let me assess the features of these that might be essential to a kind made up out of them, one we might call a firm. In due course I want to suggest that as well as commonalities there are essential differences here, in particular between the sole trader and business partnership, on the one hand, and the limited company, on the other (turning on a process of incorporation, elaborated below). But for now, rather than draw a distinction between types of firm, I focus on that which holds between the firm and non-firm.

If the focus, then, is on the sole trader, business partnership and limited company the following it seems to me are the commonalities. Each, as noted, is a type of community and the commonalities relate to conditions to be satisfied in order to become a token or member of the relevant firm type. There are essentially three such conditions or requirements currently in the UK. First, for a particular community to qualify as one of these entities, it has to be appropriately legally positioned or registered. Second in order to qualify for registration, the particular community has to possess a legal structure associated with one of these positions. Third all such legal structures presuppose a conception of the set of capacities of the community that any would-be firm must possess, and which, upon positioning, are to constitute the community's characteristic function. Let me consider each requirement in turn.

\section{The requirement of positioning}

I have argued that for a specific social phenomenon or entity to be constituted as an example of a particular type, the wider or national community in which the phenomenon emerges must, through its sub-committees, both delineate the bases of different positions, and allocate the entity to one of the those positions. It involves processes of 1) position constitution, and 2) positional allocation of phenomena.

It follows that, for a particular community of the wider society to be constituted as a sole trader, business partnership or limited company, it is sufficient that there be within the wider community the recognition and maintenance of the positions Sole Trader, Business Partnership and Limited Company, as component locations of the wider community structure, and that the particular (sub) community in question is allocated to the relevant one.

This is indeed the case, and in the UK currently it involves a process of legal registration (with Her Majesty's Revenue and Customs [HMRC] in the case of the first two and with Company's House in the case of the limited company). This is the process of acceptance (by an agent of the legal community) of the sub-community in focus as being positioned (within 
the wider, typically national, community) as either a sole trader, a business partnership or a limited company ${ }^{18}$.

On being so positioned, the community in question thereby gains the identity occupant of the social position Sole Trader, or Business Partnership or Limited Company - more briefly it is constituted as a sole trader, business partnership or limited company - and, if amongst other things (more is involved especially in the case of the limited company - see below), has certain of its causal capacities interpreted as its positional function set. In all such cases the community in question is constituted as a firm ${ }^{19}$.

\section{The requirement of an appropriate legal structure}

If being so positioned or registered is sufficient for a community to be constituted a sole trader, or business partnership, etc., a current requirement it must first satisfy in order to be so positioned is that it must have the appropriate legal structure. By the term structure, here, I include a community-specific set of positions and their organising sets of rights, obligations and collective practices (which will of course determine the control of, and access to, specific sets of assets and so forth). Any such structure, of course, is contingent and the range of feasible structures will vary over time. Mostly, though, such structures relate to the rights and obligations of community members with regard to receipts of profits and payment of taxes, etc., and so are constitutive features of the entities in question.

I have already noted that the position Sole Trader is not restricted to individuals working alone but rather is open to organisations in which one person alone is responsible for the business. This person is interpreted as 'running' this business as an individual. As might be expected in any community where one individual assumes responsibility, that individual can decide alone the manner of use of (including whether to keep all) the business' 'profits', albeit after meeting all tax obligations (the latter include sending a self-assessment tax return each year to HMRC; paying income tax on profits and National Insurance; and registering the business for VAT if annual revenue is expected to be above a certain amount). Equally this single individual must assume responsibility for meeting any losses the business makes, and paying bills for things bought for the business, like stock or equipment, and keeping records of business' sales and expenditure.

The legal structure associated with the position (ordinary) Business Partnership is constituted along similar lines to that of Sole Trader except that each of its occupants is a group of individuals or 'partners' who personally share responsibility for their business. As might be expected of any community where responsibility is shared, the business' profits can be shared between the partners, and each pays tax on her or his share. Each partner is additionally personally responsible for a share of any losses the business makes, as well as for a share of the bills for things purchased for the business, like stock or equipment (Incidentally a partner does not have to be an actual person; because a limited company counts as a 'legal person' it can also be a partner in a partnership -- a matter I eventually get to below).

\footnotetext{
${ }^{18}$ To appreciate the importance of tax law in firm constitution see e.g., Robé, J.-P., 1999, or Deakin, 2003.

${ }^{19}$ I focus on the limited company in due course below. Currently, to set up as a sole trader in the UK, a community as noted has to be registered as such with Her Majesty's Revenue and Customs (HMRC). This is done by the individual controlling the firm. To set up as a business partnership one individual must become the 'nominated partner', who is responsible for keeping business records and managing tax returns. The nominated partner must register the business partnership with HMRC. On so doing he or she automatically registers personally for 'self-assessment'. Otherwise the legal implications are much as for the sole trader with the 'nominated partner' incurring the administrative generalised liabilities of the individual with responsibilities as a sole trader.
} 
The legal structure associated with the position Limited Company is more complex. Amongst other things, it is necessary for a firm or community to nominate or appoint directors who may and often will run the company ${ }^{20}$. Each company is also required, currently, to have at least one shareholder (or two for a public company), and each would-be company has to submit a 'statement of capital' indicating the number of shares the company has and their total value (known as the company's 'share capital') along with the names and addresses of all shareholders (known as 'subscribers' or 'members'). It is sometimes supposed that where a company comes into being the shareholders are its owners, though with a company being ultimately a (positioned) community, of which the shareholders are 'members', this supposition seems dubious and unhelpful at best (depending on the interpretation of ownership- see section VI below), albeit the shareholders certainly have powers to vote and to agree on changes to any company. It is probably best to think of shareholders as owning instead a certificate (or possibly being merely in receipt of an email confirmation of purchase shares) that entitles them to certain returns from the company. I will discuss the meaning of 'limited liability' in due course. For now I merely note that before a would-be firm can register as a limited company it is the case that, as for sole trader and business partnership, a legally specified structure is required.

\section{The requirement of capacity to perform the accepted function}

Third, and finally, an examination of the requirements in terms of legal structures associated with the various positions in question reveals that a general economic orientation is presupposed (and in that sense required or expected) in each case. Specifically, it is presumed (especially in the various rules concerning how profits can be distributed and are to be taxed) that the community has the capacity for, and is concerned with, the co-ordinated production of goods and/or services to be sold to others, in a way that is intended to be advantageous to (at least some of) the community members, with (at least some of) that advantage interpreted as 'profits'.

This economic function of the firm is also clear from a consideration of regulations governing exceptions to the requirement of registering; the latter being communities that organise for collectively co-ordinated activities that do not include profit seeking.

These do not need to be so registered as a type of business. Rather they are referred to as 'unincorporated associations' and constitute organisations set up through an agreement between a group of people who come together for a different, e.g., a voluntary group or a sports club. In such cases it does not cost anything to set one up; and individual members are personally responsible for any debts and contractual obligations. This isn't a legal structure, and indeed any such association is not actually recognised as such by the law. This is not a firm (though see discussion under 'qualifications' below).

In short, when a community becomes registered as a sole trader, business partnership or limited company the capacity that becomes interpreted as its positional function set (i.e., function set qua a firm) is precisely the co-ordinated production of goods and services to be sold to others, in a way that is intended to be advantageous to (at least some of) the community members, with (at least some of) that advantage interpreted as 'profits'. In being so constituted the community is in effect being placed as a recognised component of the

${ }^{20}$ It is not essential, i.e. a matter of law, that directors run a company in the sense of running its operations. This can be delegated to others while directors maintain a monitoring role. 
industrial structure of the community as a whole. Its intended positional function, to repeat, is profitably to provide goods and services to others.

So a firm, at least in the common forms of sole trader, (ordinary) business partnership and limited company, is legally constituted ${ }^{21}$. There is no conflict of economic and legal conception. This is because the community is organised with the intent of achieving an economic goal, and the legal system determines the sorts of structures to which any such community must conform if it is to be accepted (positioned) as a firm by the wider (typically national) community which the legal system serves, and of which it is, in turn, a particular sub-community.

\section{Qualifications}

It is important that I now briefly qualify the picture given, or at least add some possible caveats. My focus, in considering the registration of the three types of firm, has been current UK tax law. A first point to make is that UK tax law has not always operated in the manner described. For example, it is only relatively recently that a sole trader had to be registered for tax purposes in the UK, and there are countries where this is not the case. But there are always processes whereby any wider community accepts (or not) a specific sub-community as a specific firm type, for example as a sole trader, whatever the context. The point then is the process of positioning is always context dependent. As it happens, currently in the UK a sole trader, like a business partnership and a limited company, is legally constituted through tax law.

Second, although the focus on tax law is sufficient to establish that currently in the UK the firm in the shape of the sole trader, business partnership, and the limited liability company is legally constituted, I do not want to suggest that other forms of law, for example, company law, employment law, and general private (contract and property), do not condition the structuring of the firm and affect its behaviour. It is important though to distinguish law that conditions all communities, or individuals, or forms of social relations, and those that bear specifically on forms of firm. In the UK, partnership law does provide a set of default terms for partnerships, and company law does the same for companies. In a sense all such factors can bear on the structuring and practices of the firm. The unincorporated association is also legally structured in this sense, for example by trust law or commercial law and specifically the law of agency. But these factors may or may not bear on the question of whether the entity in question is constituted as a type of firm (as opposed, say, to matters of its regulation, as to whether the entity, say a firm, is acting (in) appropriately ${ }^{22}$. However that may be the firm has a legal constitution via tax law at least. It is the latter that is directly involved both in positioning a type of firm and in determining the basic legal structure necessary for it to conform to a community becoming a sole trade, partnership or limited company ${ }^{23}$.

\footnotetext{
${ }^{21}$ For an early contribution recognising the legal manner of constituting the firm see Geoffrey Hodgson (2002)

${ }^{22}$ Many of the relevant issues are discussed in Deakin, 2003, 2011, 2012.

${ }^{23}$ An interesting additional case to consider is the classification of the special purpose entity (or vehicle). This is a legal entity, usually a limited company of some type, that, as its name suggests, is created (usually by an existing 'sponsoring' company) for some very specific (set of) purpose(s). These purposes usually take the form of acquisition and/or financing and/or management and/or use of specific assets. The entity so created is usually a subsidiary company with an asset/liability structure and legal status such that its obligations are rendered secure even if the parent or establishing/sponsoring company goes bankrupt. To establish independence from a sponsoring company any special purpose entity will often be set up as an 'orphan' company with shares settled on charitable trust and with professional directors provided by an outside administration company. Still there must be directors somewhere. The entity in question is an organised sub-community positioned/registered as a real company with its own separate legal identity, and subject to the laws and regulations of the country of domicile. In addition to directors, the entity will need at least a company secretary and a registered office, etc.,
} 
A third qualification turns on the use of the category firm itself and on my assertion above that the 'unincorporated association' (that is, a community that organises for collectively coordinated activities that do not include profit seeking) is not a firm. Of course, if an opponent of the view I am defending -- perhaps pointing to the fact that in the past manufacturing companies often took the form of an unincorporated association -- insists that such associations also are firms, the latter is not a position I can refute; the issue is one of how to best to allocate categories. Clearly though, if the term 'firm' is used to cover unincorporated associations, and perhaps other communities, the outline above, which is already fairly abstract, would have to become far more so. Instead, of identifying the firm in the manner outlined above as being legally positioned, legally structured, and possessing the noted economic function, we could say of any firm only that it had been a) appropriately positioned according to wider-community collective practices; b) appropriately structured; and thereby c) organised collectively to achieve some particular function. In this scenario, the sort of entity I have been outlining might then merely be termed a for-profit or possibly a business firm.

In the absence of any collective agreement on the use of the category the taxonomic strategy is a matter of choice. Many and seemingly most accounts, though, clearly do restrict the term firm to cover for-profit entities, whatever considerations may otherwise differentiate them, and I shall adopt this convention hereafter; though I acknowledge that there are other imaginable terminological strategies available.

I might add at this point that terminological complications do not stop with the category firm. I am about to embark upon a discussion of the peculiarities of the limited company. The fundamental process to be examined here is that of incorporation, the latter being a notion I elaborate upon below. For consistency with the discussion so far, I will be following the official UK usage of terms, and so I shall refer to a firm that has been incorporated precisely as a (limited) company. It will be seen, however, that the process of incorporation is not restricted to firms as understood here, not all companies are for-profit, and in the UK the generic term for anything incorporated is the corporation (thus, in the UK the term corporation also covers non-profit making communities, such as the City of London Corporation). I note as well that in US terminology, one that is adopted by many academic contributors, the term corporation is used approximately in the manner that the term company is used in the UK (whereas in the US, the term company means more or less any [organised] community). Hopefully, my usage of categories will be clear from context.

However, one feature I will consistently maintain is that all usages of company and corporation will be for entities that have been incorporated (a process as I say that I will describe below). Thus, I will also sometimes refer to a company as a firm qua company or as a firm qua company/corporation. This will be to distinguish such a firm from an unincorporated firm. For the latter the adjective 'ordinary' will sometimes be used, as in 'ordinary firm', or 'ordinary business enterprise', or 'firm qua ordinary business', etc.

Before I do turn to such matters, it is worth noting that the analysis of the nature of the firm

with all such components appropriately positioned and organised by a coherent system of rights and obligations ensuring the maintenance of statutory books, the making of statutory filings of audited accounts, tax returns and other company matters, etc. In addition the entity's characteristic function or 'special purpose' will confirm to the economic one I have associated with firms even if taking a very specific form. The special purpose entity is a community qua firm even if a somewhat special case. 
so far laid out has been achieved without necessary reference to processes of incorporation, or related ideas (as we will find them to be) of legal fictions, or legal persons etc. The specific firm type of limited company, it will be seen, is indeed a form of incorporated firm. But in setting out how it is most basically constituted as both an economic and legal entity, the process has not been found to be different in relevant respects to those of other (unincorporated) ordinary business enterprises discussed. In short, in all cases it depends on appropriate community positioning. In other words, in all cases the firm, given the coverage of the latter term accepted here, can be understood as follows:

The (modern) firm is simply a specific community, currently legally positioned, that is formally registered, within the wider, typically national (or international), community, as an emergent sub-community of the latter, oriented to the collectively co-ordinated production of goods and/or services to be sold to others, in a way that is intended to be advantageous to (at least some of) the community members. It is normally the case that (at least some of) that advantage is interpreted as 'profit'.

Of course, and as already noted, and even accepting the noted caveats and qualifications, this formulation remains somewhat abstract. A feature that is concealed by this conception is the manner in which the goods and or services (to be sold to others) are produced. This turns on the specific inner constitution or relational structures whereby the community is internally organised in pursuing this end. Under modern capitalism such relational structures, which of course always involve power relations, take various forms, and mostly are structured hierarchically so that certain individuals may benefit significantly from their power over, and at the expense of, others ${ }^{24}$. Certainly, these structures typically allow a transfer of resources to (the more) powerfully positioned members of the communities both from any other less powerful community members, and also from non-community members. But that said, there is no a priori reason that a firm is always so structured, at least internally, especially where it is family based or a co-operative etc. The point is that however the community is structured in detail, any structure that allows the community to meet the conditions of the italicised paragraph above will constitute a firm in the UK, so I take the above noted conditions, though warranting supplementation to characterise any specific firm, to be sufficient to distinguish any community as a firm.

Although, this conception has been arrived at without explicit reference to any process of incorporation (even though the latter is essential to the constitution of a limited company as a type of firm), it is necessary now to turn to the latter process. After all most modern firms are incorporated as companies. Moreover, the idea of incorporation, if fundamental to developments in the modern capitalist world, appears regularly to give rise to contrasting conceptions of the mechanisms in place. So I now turn to consider the process of incorporation systematically and at some length, and so finally seek to identify the relevant peculiarities of the limited company/corporation. To this point I have been concerned to distinguish the firm from the non-firm. From here onwards, as I say, I am concerned to distinguish the incorporated firm (qua company) from the unincorporated one.

\section{The company/corporation}

So what is going on when a firm is incorporated as a company, and in particular a limited company? How in addition is it possible to make sense of the widespread talk of such

\footnotetext{
${ }^{24}$ This includes the powers of those in control over the firm's managers - see Raghuram G. Rajan and Luigi Zingales, 1998, 2001. Also see Lawson (2012).
} 
companies being (legal) fictions, or (analogous to) real persons, and so on. I think the ontological conception elaborated helps us systematically to sort through some of these issues.

A preliminary point to make is that, because any firm is a real community, it is evident that through its undergoing a process of incorporation, whatever may be involved, the firm, now taking the status of a (limited) company, is not going to be somehow rendered thereby an ontological fiction, or non-existent as an entity. Nor of course will it be a real person. So, why is it the case that the company is so frequently represented using these terms? What really is the nature of the company, i.e., the incorporated firm, the firm qua corporation?

Briefly, before I answer this set of questions, I note as a second preliminary observation that the position of (Limited) Company is available not merely to new 'start-ups'; certain communities already (legally) positioned/constituted as firms, say as business partnerships, also have the option to incorporate as companies. So, to repeat an observation of the previous section, something is involved over and above the mere establishment of a type of firm. The separate conceptual steps that are implicated are somewhat masked by the fact that a firm may indeed also come into being directly in the form of a company, having never been unincorporated. My claim here, though, is that conceptually two separate processes are always involved, albeit that in the just noted case, where a firm starts out as incorporated, these two processes are being combined so as to appear legalistically as one. This is a claim I need to elaborate.

\section{Multiple positioning}

Fundamental to understanding the nature of the incorporated firm here is the idea of double or indeed multiple social positioning. For purposes of illustration, consider first the example of positioning of a single human individual. One and the same person may be positioned simultaneously in somewhat separate communities, as for example a father, a doctor, organiser of a local dance club, member of a reading group, and so on. This can be called multiple horizontal positioning, because the positions are merely different.

But any given individual can also be multiply vertically positioned, as when each of a set of positions is nested in, and/or nests, others of the set. Thus, a particular individual may be a gendered woman, citizen of the UK, a Member of Parliament in the UK, a member of the UK shadow cabinet (say as the UK shadow foreign secretary), and so on. In this case an individual does not so much join separate communities as move into evermore nested subcommunities of one already occupied (with advancement up a status hierarchy). Once a gendered woman born outside the UK, say, is accepted as a UK citizen, then she may stand for Parliament, and if elected then....; and so on.

Similarly an artefact maybe multiply horizontally positioned in various systems. For example, a computer may be positioned as a time keeper, a mailer, a component of a music system, a filing system, and so on.

More relevant for the current discussion, an artefact can also be multiply vertically positioned in various systems. For example an item of clothing of certain colour and constitution may serve as a football shirt to be worn to protect the wearer from the elements when playing the game; as an identifier at the team level (when each member wears the shirt, to help other team members and fans to quickly recognise which side the player is on); as club 
merchandise (to be sold to fans world-wide); as an advertising device for the club's sponsors etc. Each of the later mentioned system functions presupposes those that were already identified.

Notice that when an artefact becomes multiply positioned it in effect accumulates additional characteristic functions, as a different set of its intrinsic capacities becomes interpreted as a characteristic function set relative to each novel layer of positioning. Thus, in the noted case of the shirt the characteristic functions that so accumulate include: serving to protect from the elements, serving to identify team membership, serving as club merchandise, and so on. In contrast, when a human being is multiply vertically positioned, and in particular moves into ever nested positions, he or she accumulates (not characteristic functions but) additional powers (rights and obligations). Thus, when a person is positioned as a UK citizen, then enters Parliament, and eventually the shadow cabinet, etc., he or she acquires an additional set of rights and obligations with each 'advance'.

I now want to suggest that the registration of a community as a (limited) company constitutes an example of multiple vertical positioning applied to a community in question, but that the process is in a certain sense a hybrid of those that are involved with the positioning of artefacts and human individuals. Let me once more briefly elaborate.

\section{Multiple vertical positioning of the firm}

In what sense is the process involved a hybrid of those just considered?

Consider first the case of a community $\mathrm{C}$ that has already been legally recognised/constituted as a firm in the form of an 'ordinary' or unincorporated business, for example a sole trader or a joint partnership. If those of its members with the power to do so seek now to incorporate this same firm, as say a limited company, the process involved includes a second round of positioning. It involves a form of multi positioning, though with a difference, rendering it a hybrid of the cases so far considered.

When this community $\mathrm{C}$ was first positioned as an 'ordinary' or unincorporated firm the positional properties that were implicated are functions (rather than powers). Specifically, the community's capacity of 'co-ordinated production of goods and/or services for sale to others at an advantage to its members' becomes its (official or legally constituted) characteristic function qua a firm.

However, when the same community (already positioned as an 'ordinary' firm) is further (following a degree of structural/legalistic transformation) positioned as a limited company or commercial corporation the positional properties that are thereby primarily implicated are powers, i.e., rights and obligations (rather than capacities/functions). Specifically, through this process of additional positioning, one known as incorporation, the firm ultimately acquires particular rights and obligations just as in the case when it is a human being that is being positioned. Modern companies for example have the right to own various assets (such as real estate, shares, cars and boats), to make contracts, to sue, and so on, and obligations entailing that they can be sued, etc. It is in this sense that it is coherent to talk of the firm positioned as a company as acquiring legal personhood, or indeed positioned as a legal person.

The process wherein a community becomes first an 'ordinary' or unincorporated business and 
thereafter a company can be considered a hybrid of the processes of multi-positioning just discussed just in the sense that in the first round of positioning it is (as with the positioning of artefacts) capacities that are recognised as being its associated characteristic function set, whilst in the second round of positioning it is (as with the positioning of human beings) access to rights and obligations that are acquired.

This hybrid case of double positioning, however, tends to be masked by the fact that some firms start up us limited companies and so do not appear to undertake processes of double/multiple positioning. But in truth they do, albeit in one go, by entering a position of Limited Company that is already nested inside another position, namely that of Legal Person.

Actually it is nested first in the position Juridical Person which, I am going to suggest, is in turn nested within (though it is sometimes interpreted as equivalent to) that of Legal Person. To see that this is so and to understand all that is really going on here, it is actually necessary at this point to take a slight detour beyond the focus on the company per se.

\section{Legal fictions and legal persons}

In fact, at this stage of the analysis it is necessary to consider the meaning of the notion of legal fiction encountered earlier. I have already suggested that various commentators associate the idea of a legal fiction with a firm or an 'organisation' and on doing so view, or encourage interpretations of, the latter as an ontological fiction, as not a real entity at all, but a mere construct that can in effect be dispensed with. Here I want to suggest that this form of reasoning is quite misleading.

The first point to make is that the expression 'legal fiction' is a legal term of art, with application far wider than discussions of the company; it is not just a loose expression applied to portrayals of the incorporated firms as somehow acting like humans.

Nor does use of the term amount to a way of pointing to other terms or categories that have no referents.

Rather, it is basically a false claim about a pertaining situation that is resorted to merely in order to adjust the incidence of a pre-existing (set of) rule(s).

If we think of all legal rules in a specific community as applying to a given set of situations, then it is possible in law to extend the application of legal rules to an additional set of situations in that same community by misrepresenting these additional situations as conforming to those of the set for which the legal rule was originally intended, even though in reality they do not. The misrepresentation of the facts of these situations in order that a preexisting rule can be applied to them is known as a legal fiction ${ }^{25}$.

Typically, and certainly of most interest from perspective of the positional framework that I have been defending, a legal fiction involves some authority (in the UK, the courts, parliament or [formerly] the crown) making a false claim about a pertaining situation to allow

\footnotetext{
${ }^{25}$ This certainly is a long standing prominent interpretation of the legal fiction, an interpretation indeed, whereby it is a device that has not always been popular. Jeremy Bentham, for example, opposed its widespread usage, writing of it that: "A fiction of law may be defined as a wilful falsehood, having for its object the stealing of legislative power, by and for hands which durst not, or could not, openly claim it; and, but for the delusion thus produced, could not exercise it" (quoted in C.K. Ogden, 1932, xviii).
} 
various individuals to access certain sets of rights and obligations where these were not originally intended for these individuals. The mechanism whereby this works is usually the creation of a legal position or status and associating with it various rights and obligations originally designed or intended for quite different positions and their occupants.

A familiar example, certainly in the UK, is the creation of the positions of Adoptive Parent and Adopted Child. The allocation of biologically unrelated persons to these positions amounts to the legal fiction that the individuals in question are - that is, that they qualify (in law) as - parents and offspring. It is a legal fiction designed to enable certain nonbiologically related adults and children to gain access to the same (legally bestowed) rights and obligations available for the benefit of those that are biologically related.

Notice that there is no ontological fiction involved here, merely a legal positioning of certain individuals as something which, without a legal interpretation, they are clearly seen not to be, in order that some outcome be achieved that could not easily be so otherwise; and specifically that rights and obligations be made available to parties for whom, in their design, they were never intended. In such cases there is always something or someone real that is repositioned. In being repositioned that something or person is not somehow rendered a fiction. To repeat, a legal fiction merely refers to a legal misrepresentation of a situation in order to allow the application of a legal rule (in particular regarding rights and obligations) to a case for which it was not originally designed or intended to cover.

As it is with the process of positioning human individuals as adoptive parents and adopted children, so it is with the process of incorporating communities as companies. The legal fiction here is that a firm is, i.e., counts in law as, a person. The mechanism is that the firm is positioned as a legal person, i.e., is allocated to the position Legal Person, providing the firm in question the right to access more specific (sets of) rights and obligations that in their design were intended only for (certain groups) of human beings.

It is not, though, only firms that can be so treated. Nor is the positioning of non-humans as legally persons a recent development. An early example is associated with Pope Innocent IV (1195-7), who used this sort of device to separate the rights and obligations of monks (who could own nothing, but could be sued for legal wrong doings) from those of their monastery (which as a legal person could own assets, but as a non-real person, lacked a soul, and could not therefore be negligent or excommunicated).

However, in modern times, it is in effect through the positioning of a firm as legal person that it becomes incorporated. It thereby acquires the right to acquire additional rights and obligations, which from time to time are determined by the courts or Parliament.

\section{Natural Persons and Juridical Persons}

It follows that in law there are in effect two categories or positions whereby the occupants qualify for legally bestowed rights and obligations, the one containing human individuals and the other containing non-human entities. In giving names to these categories and so the associated positions there is once more, however, a terminological difficulty with which to contend.

The precise term most frequently used for the legal position in which a firm is situated to qualify for rights and obligations is that of Juridical Person; and this is distinguished from 
Natural Person which is intended only for (some) human beings. On some accounts Legal Person is an overriding idea or position containing Natural Person and Juridical Person as two nested positions. The foregoing represents the terminological convention I shall adopt. However, on other interpretations Juridical Person and Legal Person are the same thing, to be contrasted with Natural person. Yet further interpretations exist.

Which terminological option is adopted does not really matter, however, so long as it is recognised that in law there is a position to be occupied only by human beings and another that can be occupied by non-human beings, where both positions facilitate the allocation of certain rights and obligations. It is important to note, though, that the ascription of rights and obligations is in both cases a legal affair. That is why I persevere with the category Legal Person as nesting positions first for human beings and second for others, positions that I am referring to respectively as Natural Person and Juridical Person.

On this conception to be a legal person, sometimes phrased as having a 'legal personality', does, as noted, strictly speaking mean to be capable of having or gaining access to legal rights and duties within a certain legal system. Legal personality is thus a prerequisite to possessing various specific rights and obligations. More formally it is a prerequisite to legal capacity, a term that expresses the rights and obligations that the entity in question can acquire and exercise within the framework of the legal system ${ }^{26}$.

Whatever the precise terminology adopted it is clear that the outcome achieved through incorporation is the acquisition of sets of rights and obligations by the community qua firm as a totality. In this way, a company per se, as earlier noted, can acquire certain specific sets of rights and obligations, such as those of owning assets (houses, boats, shares, etc.), contracting, suing, and being sued, and so on. As a result there is a separation between those rights and obligations that accrue to individual members of, or participants in, the community now incorporated as a company, and those that accrue to the company itself viewed as a legal person. What then is the advantage of this separation, deriving from granting a company per se the right to acquire the noted rights and obligations?

Essentially, if somewhat abstractly, it is to allow both the firm as a whole and the individual members to be protected from the misdemeanours, financial failures, and particular limitations (humans die and pay death duties, but companies might last for centuries) of the other.

With incorporation a company issues shares. The most common form of company is a private company limited by shares ${ }^{27}$. This is an (incorporated) company whereby, in the face of

\footnotetext{
${ }^{26}$ In modern times, it is through being positioned as Natural Persons, typically at birth in a country, that individuals acquire legal capacity. Clearly, though, throughout history specific groups of person have had their freedom or capacity restricted. Some have had restricted freedom of movement; others have never achieved, or have had withdrawn, the right to vote, etc. English law, for example, used to treat married women as lacking the capacity to own property or even to act independently of their husbands (the last of these rules was repealed as recently as 1973, with the Domicile and Matrimonial Proceedings Act, which removed the wife's domicile of dependency for those marrying after 1974 so that a husband and wife could have different domiciles). In Roman and early Germanic law, slaves had no legal rights or duties, and were treated merely as legal objects/property. Under Roman law, in fact children born with severe deformities, known as monstra, could be killed with the permission of a magistrate. As societies have developed, and various forms of intergroup oppression have formally ceased, many 'incapacities' have been removed. In fact, in modern legal systems, 'capacity' is the principal juridical mechanism by which individuals and entities are empowered to enter into legally binding agreements and, more generally, to arrange their affairs using the instruments of private law (see Deakin and Supiot [eds.] 2009, for a rare if detailed discussion of these sort of issues).

${ }^{27}$ Other forms of company include the private company limited by guarantee, wherein directors or shareholders financially back the organisation up to a specific amount if things go wrong; or the private unlimited company where directors or
} 
financial problems, the shareholders' liability is limited to the original value of the shares issued but not paid for.

Thus, suppose a particular shareholder has, say, 1000 shares in the limited company originally valued at $£ 1$ each. If the company fails, and at the time the company fails this individual shareholder has paid for 100 of these shares, it means that he or she is liable only up to the original value of shares yet to be paid for, namely $£ 900$. Importantly the shareholder is not liable for the full loss of the company where the latter exceeds the shareholder investment. So in a company, shareholders, directors and officers typically are not liable for most of the company's debts and obligations. Rather any debts run up by the firm qua company are rationalised as those of the company, not of the shareholders. For this reason, a company tends to be referred to as a business with limited liability, noting that it is the shareholder, not the company per se, that has limited liability ${ }^{28}$.

In comparison, in the case of an unincorporated business, the sole proprietor or general partners in a partnership, etc., are personally or jointly responsible for all the liabilities of the business, such as loans, accounts payable and legal judgments, etc.

In similar fashion, because the company is considered a legally separate entity, it and its assets are protected from the misdemeanours of individual members of the community and in particular the shareholders. Where a shareholder is personally involved in a lawsuit or bankruptcy, etc., a creditor of a shareholder of a company cannot seize the assets of the company. Or rather the creditor can seize shares in the company only in as far as they are considered a personal asset of the shareholder in question. This is known (not as limited liability for the company but) as asset partitioning.

It follows as a further benefit of incorporation that 'ownership' claims (whatever their actual status) on a business are more easily transferred to others. Where a firm is unincorporated the process of selling or giving away ownership claims can involve a complex process wherein property is retitled, new deeds are drawn, and other administrative chores need to be undertaken. In the case of a company, all of the owners' rights and privileges are represented by the shares of stock they hold, which can be easily and quickly transferred, usually merely through adding a signature.

In turn, the ease of transferability of shares, along with limited liability makes incorporation attractive to new 'investors'. And of course, as incorporation renders a business a legally constituted component in a wider legally constituted totality it provides access to a reliable body of legal precedent to guide owners and managers in their conduct.

There are then various perceived advantages of incorporation. These along with the widespread current acceptance of the factors involved, encourage an impression that the limited liability company is a natural feature of the social landscape. Indeed, the idea that

\footnotetext{
shareholders are liable for all debts if things go wrong, and the public limited company where shares are traded publicly on a market, like the London Stock Exchange.

${ }^{28}$ Of course, there are exceptions or better limits to limited personal liability for those who own shares in a company. The latter shareholders may be held personally liable if, for example, they personally and directly injure someone; or personally guarantee bank loans or business debt on which the company defaults; or fail to deposit taxes withheld from employees' wages; or intentionally do something fraudulent, illegal, or reckless that causes harm to the company or to someone else; or treat the company as an extension of their personal affairs, rather than as a separate legal entity. In the latter case a court might decide that in this case the company as such does not really exist and find that its owners are in effect doing business as individuals who are personally liable for their acts.
} 
more or less any firm or would-be firm can be incorporated as a limited company is currently somewhat taken for granted. It is worth recalling, however, that even following the introduction of the idea of legal personhood into the UK the path leading to the current situation has been anything but smooth. Contestation has longed raged over the types of communities that could be positioned as legal persons, the specific rights and obligations that could be acquired for those that were so positioned, as well as over which bodies were to make any relevant decisions regarding the accessing of such rights and obligations. In particular, from the outset, and regularly since, the idea of granting legal person status to profit-seeking communities has been severely resisted. A brief consideration of these matters is likely useful in conveying how the current components of the process of incorporation were never a natural unity.

\section{The origins of the modern company}

In fact, prior to the seventeenth century the only communities in the UK that were positioned as legal persons and so qualified as corporations were not-for-profit entities ${ }^{29}$; they comprised charities like schools, universities, hospitals, churches, etc., and eventually municipal councils. As such these corporations had various rights such as owning buildings, land, and so forth. Notably each also possessed constitutions drafted and approved by the crown or the government, which set out their rights and obligations along with the objects the corporation sought to attain. If a corporation acted inconsistently with its constitution, that is, if it acted "ultra vires" or beyond its legal powers, the courts had the power to declare the offending actions void and unlawful. During this time, for any such charitable community to undertake commercial activities in order to make a profit was clearly ultra vires.

It is also interesting to note that when the UK's first profit seeking corporation, the (English) East India Company, obtained that status in the early $17^{\text {th }}$ century, it did so in a manner that was seemingly unlawful ${ }^{30}$, that is, it came to occupy the position Corporation not via any action of the crown, government or the courts but through the actions solely of its members.

Towards the end of the $16^{\text {th }}$ century the crown granted charters of incorporation to "trade associations'. These thereby became non-for-profit corporations. They did not carry out trade in their own names, but were granted a monopoly over a specified area of trade. Business partners could become members of the trade association and thereby entitled to carry out business in that trade. However for any such partnership, the firm would trade separately, with its partners sharing ownership of the firm's assets, as well as responsibility for its activities.

The English East India Company started as one such trade association. It received its royal charter in 1600, enabling its members to share in the monopoly on trade in the East Indies for the next 15 years. In the period that followed the individual member/partners took a highly significant series of actions. First they started to amalgamate their stock until they became one large partnership, jointly owning all the stock, and carrying out all the trade. Later the ownership of this (jointly owned) stock was transferred to the company itself (which being a corporation was allowed to own assets). In place of their shared ownership of the stock of a business partnership they acquired a share in the joint stock of the corporation itself. The corporation subsequently, traded this stock in its own name and made its own profit, which was then distributed amongst the members/shareholders. In this way the East India Company

\footnotetext{
${ }^{29}$ The device of incorporation likely came to the UK as a result of the Norman Conquest.

${ }^{30}$ See Lawson 2015, Spencer, 2004.
} 
became the first UK corporation to operate for a profit (On all this see Lawson, 2015).

Although in all this, the members of the company were acting in a manner that was almost undoubtedly ultra vires these actions went unchallenged in the courts and elsewhere. To the contrary, up until the Bubble Act of 1720, the crown, on observing the apparent successes of the East India Company, began to grant charters to new companies expressly for them to trade as commercial corporations. Eventually, new commercial corporations were formed by both royal charter and act of Parliament to develop new patents and domestic trade, by this time seeking outside investors to provide the finance ${ }^{31}$.

However by the start of the $18^{\text {th }}$ century highly suspect corporations were being unmasked, with individuals masquerading as commercial corporations to fraudulently seek out investors funds. In addition the South Sea Bubble and other financial scandals of that time caused further losses to investors. But with corporations bearing the responsibility (rather than shareholders) the victims could not easily get recompense; nor could the courts penalise them (as corporations for example could not be imprisoned). So the government felt a need to rein them in. Many were wound up or nationalised. And the Bubble Act of 1720 legislated that all commercial undertakings (not just in corporations) would be illegal that tended "to the common grievance, prejudice and inconvenience of His Majesty's subjects". The law also banned speculative buying and selling of shares; they could be bought only by persons genuinely taking over a role in running a firm.

Everything changed again between 1825 and 1856, however, as a series of Acts of Parliament relaxed the controls on the creation of commercial corporations. It was during this period that the idea of limited liability became established ${ }^{32}$. The primary reason for the change was the building of the railways requiring large agglomerations of capital. The way of achieving this was through chartered joint stock companies. By 1840, 2000 miles of railway track had been laid all financed by chartered joint stock companies (Micklethwait and Wooldridge, 2003, p. 47).

Even so, right into the late $19^{\text {th }}$ century the courts were still reluctant to give shareholders the full benefits of limited liability or indeed to fully recognise that profit seeking corporations had separate legal personality; and they made it clear in a series of rulings that in their view the courts controlled corporate behaviour.

However developments were never smooth, and there were a number of successful challenges to court rulings ${ }^{33}$. Despite this the courts continued to maintain the doctrine of

\footnotetext{
${ }^{31}$ Commercial corporations gained clear trading advantages over business partnerships. They could continue to exist even if the original partners died or transferred their shares. In this way they could avoid death duties. They could bring and defend legal actions in their own name rather than the names of the partners. Because assets belonged to the company per se (and not shareholders) they could not so easily be used to pay the debts of particular shareholders experiencing bankruptcy, and so forth.

${ }^{32}$ In 1825 the Bubble Act was repealed, allowing shares to be freely traded. In 1844 William Gladstone (then President of the Board of Trade) pushed through the Joint Stock Companies Act. This allowed companies to dispense with the need for a special charter; thereafter they could be incorporated by a single act of registration. However, it did not include the right for shareholders of automatic limited liability, which was strongly opposed by many liberals. Limited liability came 10 years later in an 1855 Limited Liability Act after a series of heated debates. This though carried various qualifications that were removed by the 1856 Joint Stock Companies Act which allowed firms to obtain limited liability with "a freedom amounting almost to license".

${ }^{33}$ Few if any were more significant than the case of Salomon v Salomon and Co. Ltd. in 1897. Mr Aron Salomon made and sold leather boots and shoes in his establishment in Whitechapel. Eventually he turned his business into a limited company. His wife and five eldest children became subscribers and two eldest sons also directors (to comply with the Companies Act of 1862 which required a minimum of 7 members). Salomon took 20,001 of the company's 20,006 shares for himself. The
} 
ultra vires, in effect restricting how a commercial corporation pursued its activities. Only with the Companies Act 1989 was this action by the courts effectively ended ${ }^{34}$.

So in short, over the course of 400 years, the state, which at first was opposed to granting corporate status to profit-seeking communities, has long sought to impose, but ultimately given up on all of, many devices and mechanisms designed to restrict corporate activity where the latter was perceived to be at odds with the public interest. If in the current situation the notion of the for-profit company or corporation is taken-for-granted, this is not the way matters have been for the most part of corporate history.

Today, however, the incorporated for-profit community, the company, is a widely accepted and indeed dominant part of the social scene, with the consequence that, as we have observed, the manner in which a firm is incorporated, parallels the sort of manner in which a community is established as an unincorporated firm. In all such cases an entity must merely be appropriately registered; where this in turn requires that it possess an appropriate legal structure, and a specific set of economic capacities that ground its primary function set.

The simple process of registration that is involved in the case of the corporation (which procures a Certificate of Incorporation displaying the company number and date of formation thereby confirming that the company legally exists) is one that has been in place since the 1844 Joint Stock Companies Act, though, to repeat, the ease, and powers, with which a community or firm can now incorporate stands in contrast to the situation when it was first introduced.

\section{Summary}

To take stock, the picture that emerges of the firm and company, at least within the UK, is as follows. The firm is any specific community that the wider UK community, through its relevant legal sub-communities, accepts as such (i.e., as a member/occupant of the social position Firm, or rather of one of Sole Trader, Partnership or Limited Company, and so as possessing the identity of a member/occupant of the relevant social position) and having a set of its (expected) intrinsic capacities interpreted as its function set, where the latter is roughly the co-ordinated production of goods and services to be sold to others, in a way that is intended to be advantageous to (at least some of) the community members, with (at least some of) that advantage interpreted as 'profits').

price fixed by the contract for the sale of the business to the company was $£ 39,000$. In an ensuing action the court found that this was "extravagant" and not "anything that can be called a business like or reasonable estimate of value." Transfer of the business took place in 1892 . The purchase money the company paid to Salomon was $£ 20,000$. It additionally gave him $£ 10,000$ in debentures (in other words, Salomon gave the company a $£ 10,000$ loan, secured by a charge over the assets of the company). The balance paid went to extinguish the business's debts ( $£ 1,000$ of which was cash to Salomon).

Soon afterwards the company got into financial difficulties holding stock it could not sell. Salomon and his wife lent the company money and he cancelled his debentures. But the company needed more money. It succeeded in obtaining a $£ 5,000$ loan from a Mr. Edmund Broderip. But Salomon's business still declined, and he could not keep up with the interest payments. Eventually the company was put into liquidation. To cut a long story short when Broderip failed to realise his unsecured loans he instituted an action claiming that Salomon was personally liable. The High Court and Court of Appeal held Salomon to be liable. However, upon appeal to the House of Lords, the latter overturned the decision arguing that a company had been duly created and cannot be deprived of its separate legal personality.

${ }^{34}$ The Act still required commercial corporations to include a statement of their objects in the constitution. But, under section 3A, The Act permitted the corporation to (a) state simply that it was a "general commercial company" and (b) that the Corporation has "power to do all such things as are incidental or conducive to the carrying on of any trade or business by it". And in section 35(1) of the same Act the law was transformed so that "the validity of an act done by a company shall not be called into question on the ground of lack of capacity by reason of anything in the company's [objects clause]". 
A company, more specifically, is any community qua firm that the wider UK community, through its legal sub-communities, accepts as such (i.e., a member/occupant of the social position Limited Company, and so as possessing the identity of a member/occupant of the social position Limited Company) and being a bearer of the associated positional rights and obligations, where the latter currently include the rights of owning various assets - such as real estate, shares, cars and boats -, of making contracts, of suing, and so on.

Slightly more succinctly, and also summarising related notions, the conception sustained is of the firm best understood as a relationally organised entity, and specifically a form of (appropriately positioned) community; of the legal aspect of a firm being (or arising from) precisely the process of positioning (of a community otherwise organised with an economic purpose or intent); of incorporation properly interpreted as a specific (legal) process of positioning of such a community; and of a legal fiction being a term of art for a situation being legally interpreted as other than it is to permit the application to it of a (set of) rule(s) that otherwise would not apply. It is the latter device that permits specific rules regarding various rights and obligations intended for human beings to be borne by a community per se, such as firm, for which they were never originally created or intended. The mechanism by which this happens involves the firm, through incorporation, being positioned as a juridical person, a form of legal person. But there is no sense in which the firm per se, a positioned community, becomes thereby, qua entity, some kind of ontological fiction. Nor is it the case that the corporation, if currently familiar and taken for granted, is something somehow natural and with a history free of contestation.

\section{Issues arising for Further Study}

I might finally note that in the light of the arguments so far laid out, various issues warranting further research and analysis can be suggested. One interesting example concerns the nature of ownership. If the firm is always a form of community, and the components of a firm include human individuals, how do any claims that firms are owned sit with the modern illegality of slavery? Nor are tensions or paradoxes surrounding the idea of firm ownership merely legalistic. I noted earlier that parts and wholes/totalities do not causally impact each other; rather parts are properties of totalities and the latter acts through its parts acting. An orchestra performs through the actions/performances of the conductor and musicians. But such considerations also suggest that a member of a firm cannot own that same firm, for this entails that (in addition to any legalistic problems relating to slavery) this individual owns him or herself, which is paradoxical at least ${ }^{35}$.

Of course, these apparent problems can all be bypassed by avoiding use of the term ownership in such contexts and talking instead merely in terms of rights (of disposal, of use, or restricting/excluding access to) specific fixed assets, and so forth. I do indeed favour this sort of solution (whereby puzzles or tensions of this sort are resolved not by deep philosophical thinking but by adjustment in language use). But even this strategy leaves open the question as to what might be meant by the (clearly historically specific) idea of ownership, and how the term actually functions in contemporary society in relation to the firm, not least where its use appears incoherent. What purpose if any is served by a reliance upon the term in a context in which its use seems both legally illegitimate and philosophically incoherent (for useful discussions of these sorts of issues see especially Tony Honoré, 1961, but also Henry Hansmann, 1988, 1996, Richard Pipes, 1999 and Simon Deakin, 2012)?

\footnotetext{
${ }^{35}$ On a rejection of the idea that the firm can be owned from a slightly different perspective see Deakin 2012.
} 
A second line of possible research arising out of the analysis is assessing whether a conception that interprets the firm as a community provides relative support for the view that the law should be used to promote the interests of all the various stakeholders in a firm rather than those of the shareholders exclusively. Let me briefly elaborate.

I suggested earlier (see in particular footnote 1) that much of the literature purporting to be on the nature of the firm follows Coase in questioning less the nature of the firm and more the reason that firms exist, seeking answers in terms of functions that firms supposedly serve. This may actually be more characteristic of research emanating from economics. For their part contributors from legal studies or corporate governance have tended to accept (albeit often in an overly uncritical fashion) these contributions from economics as realistic, and instead viewed their own task as applying the results of economists. Specifically, these latter contributors have sought either to use these claims from economics to reveal the economic structure of the legal framework underpinning the firm, or to theorise, and thereby reinterpret or otherwise modify, the workings of relevant aspects of the legal system so that it better facilitates the firm's functions as identified in economics. In so doing contributions from legal studies too have contributed less than usually supposed to the actual task of elaborating the nature of the firm ${ }^{36}$.

In the latter legal studies, at least since the mid-nineteenth century, two basic ideals for the firm qua incorporated entity have influenced most of the suggested reforms of legal theorists. These have been the shareholder ideal that all activities within the firm are ultimately the responsibility, or for the benefit, of the shareholders, and the stakeholder ideal that companies are responsible to a wide range of groups in the wider community.

For the most part, it is versions of the shareholder ideal that have tended to dominate. This ideal has been manifest in particular in interpretations in terms of the 'shareholder primacy model' portraying the firm as a nexus of contacting relationships. From this perspective the firm is viewed as a response to a conflict of interests (between the contracted principles and their agents in the firm). Much of modern corporate law that is inspired by economics seems to accept this sort of view of the functioning of the firm. The analysis set out above, however, centring on the firm as a form of community, may appear to lend relative support for some sort of stake holder notion. We have seen that a conception of the firm as a nexus is unsustainable, and it is equally clear from the firm as a community perspective that both the unincorporated and the incorporated firm are far more than units for resolving supposed agency antagonisms (whilst neither, qua communities, can seemingly be coherently owned anyway). It cannot be denied that there are competing interests within the firm. But this just renders the firm like any other community.

Simon Deakin (2012) adopts this sort of orientation in a recent interesting contribution that, though not especially philosophically oriented, nevertheless sustains a conception of a sort that resonates with that maintained here. Deakin recommends in particular that the firm be treated as a 'commons', as a collectively managed resource, relative to which there are competing interests, and various "overlapping and potentially conflicting property type claims on the part of the different constituencies or stake holders that provide value to the firm" (p. 381). Deakin's goal is that corporate law be based on this conception, and used to

\footnotetext{
${ }^{36}$ Early examples, of this sort of reasoning can be traced to the 'law and economics movement' inspired especially by Richard A. Posner's acceptance of, and response to, Coase's early transactions cost minimisation theory of the firm's function (e.g. Posner, 1972).
} 
make the firm more workable, not least through seeking to ensure that the different stakeholder groups are able to participate adequately in the formulation of the rules governing the management and use of those resources ${ }^{37}$. The analysis of the current paper suggests that stake holder conceptions such as Deakin's are, relatively speaking, more philosophically grounded than hitherto appreciated, and on that basis at least seemingly deserving of greater attention than currently afforded.

The sorts of issues just raised do, I think, also relate to the question raised by Adler (2001) and others as to whether there not only should be, but actually is, a trend to greater collaboration amongst the various members of the communities involved in commerce. Adler does not always put it quite like this. In fact, Adler (2001) and others counterpoise the idea of the firm as a community interpreted as an 'organisational form' based on mechanisms of trust, to other 'organisational forms' and specifically the market form coordinated by prices and hierarchical forms coordinated by authority. I earlier rejected this sort of contrast suggesting that all social emergents or 'organisational forms' containg human beings as components are, or are aspects of, forms of community ultimately based on trust. The feature that I suspect Adler and others are getting at is a distinction I elsewhere make and discuss between a community in itself (the general case) and a community that is additionally for itself (the special case) ${ }^{38}$. From this perspective Adler's thesis of a "trend towards greater reliance on trust" (p. 216), might be reinterpreted as a trend towards participants becoming reflexively self-aware of themselves qua community members, as components of communities for themselves (a trend that might be said to apply across firms where different firms are organised through inter-firm relations of various sorts to provide a community of firms).

This trend, if present, would presumably manifest itself as a tendency towards collaboration based on common purpose rather than opposition based on difference. Perhaps the emergence of contributions by those such as Deakin just noted support Adler's contention. Such a tendency, if it were indeed in play, would presumably mostly reveal itself in public acknowledgement of certain shared values by community members, more attention to common interests, and a greater willingness to seek collaborative resolutions where positional interests diverge. It would be interesting to see if empirical research bore this out.

The analysis set out bears implications too for those who think that corporations specifically, and in particular multi-national corporations, should be subject to more effective national regulation. Multinationals are often the focus of criticism due to practices of transfer pricing and other related activities that reduce the ability of national or regional governments to tax or otherwise affect their activities in the countries in which they operate. Though it would take too much space to develop the contention here, it is clear that all these activities (and numerous others - see Lawson 2015) are enabled by the sorts of multi-positioning of firms

\footnotetext{
${ }^{37}$ Deakin himself expresses matters as follows:

"The firm is best seen as a collectively managed resource or "commons" which is subject to a number of multiple, overlapping and potentially conflicting property-type claims on the part of the different constituencies or stakeholders that provide value to the firm. Drawing on the theory of the commons, this paper has argued that the sustainability of the corporation depends on ensuring proportionality of benefits and costs with respect to the inputs made to corporate resources, and on the participation of the different stakeholder groups in the formulation of the rules governing the management and use of those resources. Viewing the corporation as a commons in this sense is the first step toward a better understanding of the role that the corporate form can play in ensuring wider economic and social sustainability"(Deakin, 2012, p. 381).

${ }^{38}$ See Lawson, 2012. This distinction may also cover the conception of O'Mahony and Lakhani, who "define communities as voluntary collections of actors whose interests overlap and whose actions are partially influenced by this perception" (2011, p.6).
} 
discussed throughout the paper, with the consequent rights of certain companies to 'own' other companies including those designated subsidiaries, in some instances relating to them as mere holding companies, and so forth.

Clearly the analysis set out above provides a framework for examining all these activities somewhat systematically, including the positional rights and obligations implicated in them. This, coupled with a recognition of the contingent nature of the modern corporation, allows the easy identification of a set of historical matters, formally contested though currently taken for granted, that might be questioned anew. These, we have seen, include the sorts of communities that are most reasonably positioned as incorporated companies via the legal fiction of the Legal Person in the form of the Juridical Person; the appropriate rights and obligations to be made available to firms so positioned; and the appropriate body for making decisions relating to all such matters. For example, many question whether it is reasonable that, as recently became the case in the UK, companies have access to rights secured in bills of human rights intended only for the protection of human beings (on all this see Lawson, 2015).

As one last suggestion let me also indicate an interesting methodological project that arises from all this. Central to my analysis is the idea that many phenomena of social reality are best understood by investigating how they have come to be positioned as they are, with all that this entails. This is the manner in which I have gone about elaborating the nature of the firm. Although, I have not had space to develop the claim I think it is clear that most previous attempts to understand the nature of the firm have proceeded very differently. Specifically, they have taken prominent examples of the firm and abstracted out common properties of observed individual examples.

The latter way of proceeding is a special case of a method that has been greatly explored by Michael Hannan and his collaborators in their studies of category formation ${ }^{39}$ The sort of approach that I have adopted, and that developed by Hannan and others, may converge on similar conceptions in specific cases; but they also may not.

The essential difference between our approaches I suspect is that whilst the approach which I adopt is in effect oriented to seeking out features common to some kind $\mathrm{X}$, a concrete universal, the approach of Hannan is ultimately based on abstracting out properties manifest in all individual members of the kind X, an abstract universal. From the perspective of my own approach, it is quite feasible that all individual members of a kind 'firm' are differentiated by most of their manifest properties or particulars, and that if so this is not a problem; they each nevertheless necessarily individuate the (concrete) universal of being a firm (of achieving membership/occupancy of a specific position that provides access to associated rights and obligations). Put differently, a firm on my conception, could never be considered a firm in virtue of some abstract property, such as say possessing bricked walls, or using a specific technology, etc., but only by virtue of manifesting the concrete universal 'firm', if doing so uniquely (i.e., differently to other firms), so that the universality involved is dialectically related to particularity in a manner that abstract universals are not. For the approach of Hannan and others, in contrast, observed differences in manifest properties are interpreted as significant and give rise to the notion of partiality of category membership; the (abstract) universal is manifest only partially (see especially Hannan, 2010).

${ }^{39}$ See for example, Carroll and Hannan 2000; Hannan, 2010; Hannan, Carroll and Pólos, 2003; Hannan and Freeman J, 1977; Hannan and Hsu, 2005; Hannan, Pólos and Carroll 2007; Hsu, Hannan and Koçak 2009; Hsu, Hannan and Pólos 2009; Pólos and Hannan, 2002. 
I suspect that it would prove to be methodologically insightful extensively to compare and contrast these two approaches (and perhaps those of others too, for example the 'no social objects merely social facts' orientation of John Searle, 2010) to social grouping as a basis to understanding the fundamentals of social reality, to identify their different scopes of relevance, if any. And so on.

I could go on. With the analysis pitched at the level of ontology, any results or insights achieved likely bear in some way on very many aspects of substantive theorising (including policy formulation) and method. The foregoing are illustrative examples. The point is that ontological elaboration functions to clear the path a little for further developments in more substantive forms of reasoning concerning the ways of acting of the firm; and the foregoing merely sketch some likely fruitful research projects of this sort that immediately come to mind given the conception of the firm defended.

\section{Final Comments and Conclusion}

A basic mechanism of all human history and development, I argue, is the creation of social positions and the allocation of people and other entities to them. In the case of artefacts, positioning results in certain intrinsic capacities of the objects being interpreted as their (sets of) system function(s) within the (positioning) community. In the case of human persons, positioning enables positioned occupants to access novel powers in the form of rights and obligations. Ultimately here too the outcome serves the functioning of a wider system, namely the community, in some way.

Somewhere in human history the idea of attributing rights and obligations to non-humans arose. The position to which non-human entities are allocated in order to obtain the right to acquire other rights and obligations is, currently in the UK, that of Legal Person. The latter includes two nested sub-positions of Juridical Person and Natural Person. A significant first historical step in this regard, at least in the UK, was the allocation of not-for-profit communities to the position Legal Person, a process of incorporation, resulting in empowered communities qua corporations. Eventually forms of for-profit communities or firm also came to be so positioned, giving rise to structured communities that eventually, albeit via a long non-linear process of significant political contestation, were manifested as the business companies/corporations of the current period.

Any community that is positioned as a firm is, whether incorporated or otherwise, qua a firm, both economic and legal in nature. Though detailed objectives, internal structures and mechanisms will vary from case to case, place to place, and time to time, the basic function of the firm is always a collectively co-ordinated production of goods and services to be sold to others, in a way that is intended to be advantageous to (at least some of) the community members, with (at least some of) that advantage interpreted as 'profits'. In this sense the firm is always of an economic nature. But as with every other social phenomenon, a social identity is obtained through positioning in a relevant community. And this, in the case of the modern firm, is, currently at least, always a legal process and condition, for the unincorporated firm as much as for the incorporated.

I have drawn out various suggestions from the analysis that bear on the goal and conduct of more substantive (including policy) work on the topic. These are mainly indicative. For implications can be drawn regarding numerous phenomena and issues that form the subject- 
matter of more substantive research. The reason for this is simply that all substantive analyses about the operation of the firm, as well as methods drawn upon in its analysis, presuppose at some level conceptions about the firm's nature. Ontology is never avoidable. The options always are only whether to leave ontological presuppositions implicit or render them more explicit, systematic and sustained. As in every other domain of research, the more that the presuppositions of substantive analysis of the firm are left implicit and unexamined the less coherent the substantive elaboration is likely to $b^{40}$. Alternatively put, it is very likely that theorisations of the conditions, persistence, consequences and potentials of the firm, along with methodological orientations to its analysis, will be better grounded if co-developed alongside explicit, systematic and sustained attempts to elaborate the firm's actual nature.

\section{Bibliography}

Adler, Paul S. (2001) 'Market, hierarchy, and trust: the knowledge economy and the future of capitalism.' Organization Science, 12(2): 214-34.

Alchian, Armen A. (1984), 'Specificity, Specialization and Coalitions', Journal of Institutional and Theoretical Economics, 140(1): 34-49.

Alchian, Armen A. and Susan Woodward (1988), 'The Firm Is Dead; Long Live the Firm: A Review of Oliver E. Williamson's The Economic Institutions of Capitalism', Journal of Economic Literature, 26(1): 65-79.

Blair, M (2004) 'Locking in Capital: what corporate law achieved for business organizers in the the $19^{\text {th }}$ century', UCLA Law Review, 62: 777-95.

Carroll G.R, Hannan MT. 2000. The Demography of Corporations and Industries. Princeton, New Jersey: Princeton Univ. Press

Cheung, Steven N. S. (1983), 'The Contractual Nature of the Firm', Journal of Law and Economics, 26(1): 1-21.

Deakin, Simon (2003) 'Enterprise-risk: the juridical nature of the firm revisited', Industrial Law Journal, 32: 97-113.

Deakin, Simon (2011) 'The juridical nature of the firm', in D. Branson and T. Clarke (eds.) Sage Handbook of Corporate Governance, London: Sage (forthcoming).

Deakin, Simon and Alain Supiot (eds.) (2009) Capacitas: Contract Law and the Institutional Preconditions of a Market Economy, Oxford: Hart Publishing.

Deakin, Simon (2012) 'The Corporation as Commons: Rethinking Property Rights, Governance and Sustainability in the Business Enterprise', Queen's Law Journal, 37:2, pp. 339-81.

Fransman, M. (1994) 'Information, Knowledge, Vision and Theories of the Firm', Industrial and Corporate Change, 3(3), 713-757

Coase, Ronald H. (1937), 'The Nature of the Firm', Economica, 4(16): 386-405.

Fullbrook, Edward (2009) Ontology and Economics: Tony Lawson and his Critics. London and New York: Routledge.

Gierke, Otto von (1900), Political Theories of the Middle Age, translated with an introduction by Frederick W. Maitland, Cambridge: Cambridge University Press.

Grossman, Sanford and Oliver D. Hart (1986), 'The Costs and Benefits of Ownership: A Theory of Vertical and Lateral Integration', Journal of Political Economy, 94(2): 691719.

Hannan, M.T 2010. Partiality of Memberships in Categories and Audiences, Annual Review of Sociology, 36: 159-81.

\footnotetext{
${ }^{40}$ Numerous advantages of ontological theorising are elaborated for example in Lawson 2003.
} 
Hannan MT, Carroll GR, Pólos L. 2003. The organizational niche. Social Theory 21:309-40

Hannan MT, Freeman J. 1977. The population ecology of organizations. Am. J. Sociol. 82:929-64

Hannan MT, Hsu G. 2005. Identities, genres, and organizational forms. Organ. Sci. 16:47490

Hannan MT, Pólos L, Carroll GR. 2007. Logics of Organization Theory: Audiences, Codes, and Ecologies. Princeton, NJ: Princeton University Press.

Hansmann, Henry (1988), Ownership of the Firm, Journal of Law, Economics, and Organization, Vol. 4, No. 2 (Autumn) pp. 267-304 .

Hansmann, Henry, (1996) The Ownership of Enterprise, Boston and London: Harvard University Press, 1996.

Hart, Oliver D. and John Moore (1990), 'Property Rights and the Nature of the Firm', Journal of Political Economy, 98(6): 1119-1158.

Honoré, A. M. (1961) 'Ownership' in A. G. Guest (ed.) Oxford Essays in Jurisprudence, Oxford: Oxford University Press, pp107-47.

Hodgson, Geoffrey M. (2002), 'The Legal Nature of the Firm and the Myth of the FirmMarket Hybrid', International Journal of the Economics of Business, 9(1): 36-60.

Hsu G, Hannan MT, Koçak Ö. (2009a), Multiple category memberships in markets: an integrated theory and two empirical tests. Am. Sociol. Rev. 74:150-69

Hsu G, Hannan MT, Pólos L. (2009b), Legitimation and typecasting: a formal theory. Res. Rep. 2010, Stanford Graduate Business School, Stanford, CA

Jensen, Michael C. and William H. Meckling (1976), 'Theory of the Firm: Managerial Behavior, Agency Costs and Capital Structure', Journal of Financial Economics, 3(4): 305-360.

Kogut Bruce and Udo Zander (1993), 'Knowledge of the Firm and the Evolutionary Theory of the Multinational Corporation', Journal of International Business Studies, 24(4): 62545.

Lakoff, George (1996), Moral Politics: What Conservatives know that Liberals Don't, Chicago: University of Chicago Press.

Lawson, Tony (1994) A Realist Theory for Economics, in Roger Backhouse, (ed.) New Directions in Economic Methodology, London and New York: Routledge, pp. 257-85.

Lawson, Tony (2003), Reorienting Economics, London and New York: Routledge.

Lawson,Tony (2012) Ontology and the study of social reality: emergence, organisation, community, power, social relations, corporations, artefacts and money, Cambridge Journal of Economics, vol. 36, no. 2, 345-85.

Lawson, Tony (2013a) Emergence and social causation, pp. 285-307 in Greco, J. and Groff, R. (eds.), Powers and Capacities in Philosophy, London, Routledge.

Lawson, Tony (2013b) Emergence, morphogenesis, causal reduction and downward causation, pp. 61-84 in Archer, M. (ed.), Social Morphogenesis, New York: Springer.

Lawson, Tony (2014a) 'What is an Institution', in Stephen Pratten (ed.) Social Ontology and Modern Economics, London and New York: Routledge (forthcoming).

Lawson, Tony (2014b) 'Comparing Conceptions of Social Ontology: Emergent Social Entities and/or Institutional Facts?', mimeo:Cambridge

Lawson, Tony (2015) 'The Modern Corporation: the Site of a Mechanism (of Global Social Change) that is Out-Of-Control?', forthcoming in: Margaret S. Archer (ed.), Social Morphogenesis: Generative Mechanisms Transforming the Social Order, New York: Springer.

March, J. G. and Simon H. A., 1958. Organizations, New York, Wiley.

Micklethwait, John and Adrian Woodridge (2003), The Company: a short history of a revolutionary idea, New York: The Modern Library. 
Milgrom, P. And Roberts, J (1992) Economics, Organization and Management, Upper Saddle River: Prentice Hall.

Nelson, R. R. and Winter, S. G., 1982. An Evolutionary Theory of Economic Change, Cambridge, MA, The Belknap Press of Harvard University Press.

Ogden, CK, (1932) Bentham's Theory of Fictions.

Pipes, Richard (1999) Property and Freedom. New York: Alfred A. Knopf.

Pólos L, Hannan MT. 2002. Reasoning with partial knowledge. Sociol. Methodol. 32:133-81

Posner, Richard A. (1972) Economic Analysis of Law. Boston: Little, Brown and Company.

Raghuram G. Rajan and Luigi Zingales, 1998, 'Power in a Theory of the Firm', The Quarterly Journal of Economics, May, pp. 387- 432.

Raghuram G. Rajan and Luigi Zingales, 2001, The Firm as a Dedicated Hierarchy: A theory of the Origin and Growth of Firms, The Quarterly Journal of Economics, August, pp. 805851.

Robé, J.-P. (1999) L'entreprise et Le Droit, Paris : PUF.

Searle, John R. (2010) Making the Social World: the Structure of Human Civilisation, Oxford, Oxford University Press

Schumpeter, Joseph (1976/1942) Capitalism, Socialism and Democracy, New York: Harper.

Spencer, Rebecca (2004) 'Corporate Laws and Structures: exposing the roots of the problem', Corporate Watch, Green Print: Oxford.

Williamson, Oliver E., 1975. Markets and Hierarchies: Analysts and Antitrust Implications. A Study in the Economics of Internal Organization, New York, Free Press.

Williamson, Oliver E., 1987. The Economic Institutions of Capitalism, New York, Free Press.

Zander Udo and Bruce Kogut, (1995) 'Knowledge and the Speed of the Transfer and Imitation of Organizational Capabilities: An Empirical Test', Organization Science, 6(1):76-92, January-February. 